\title{
Development of Children's Literature Reading Materials to Support SDN 028228 Binjai Student Literacy Activities
}

\author{
Meta Melisa Br Ginting ${ }^{1}$, Mutsyuhito Solin ${ }^{2}$, Wisman Hadi ${ }^{3}$ \\ 1,2,3Postgraduate Program in Indonesian Language and Literature Education Department, Universitas \\ Negeri Medan, Indonesia \\ Email:metamelisa88@gmail.com
}

\begin{abstract}
This research is motivated by the lack of availability of reading materials for children's literature, reading materials that are not suitable for the age of growth and development of children's psychology, then students have an interest in reading, and reading habits are not yet entrenched, so it is necessary to develop varied reading materials and support students in activities. literacy. Children's literature reading materials are needed at SDN 028228 Binjai to support students' literacy activities. This study aims to determine the results of the development of children's literature reading materials in the form of comics to support literacy activities of SDN 028228 Binjai students. The research method used was research and development (Research and Development) by Borg and Gall. The results showed that (1) The reading material development process was carried out in several stages, namely preliminary studies, initial product development and product testing. (2) The results of the reading material feasibility test show that (a) the result of the material expert's validation on the reading material as a whole is $83.3 \%$ with the criteria of "very good". (b) the results of the validation by design experts on the reading material as a whole obtained data $88.3 \%$ with "very good" criteria. (c) the results of the overall classroom teacher assessment of the reading material obtained an average of 91\% with the criteria "very good" (3) The results of the effectiveness of the development of reading materials show that (a) the results of individual trials on reading materials obtained an average of $79.6 \%$ with the criteria "good ", The results of small group trials on reading materials obtained an average of $88.2 \%$ with the criteria" very good ", limited field test results on reading materials obtained an average of $90.1 \%$ with the criteria" very good ". (b) the results of the quality of using children's literature in the form of comics to support students' literacy activities were obtained an average of $88.65 \%$ (posttest), while before the use of children's literature in the form of comics, the average was $68.40 \%$ (pretest). The difference in value is $20.25 \%$ which means that children's literature reading material in the form of comics can improve the results of students' literacy activities from before. The implications of this research are (1) children's literary reading materials to support students 'literacy activities can increase students' knowledge of North Sumatra folklore; (2) the results of this study can enrich the treasury of science in order to increase creativity in the development of reading materials, especially those related to the development of children's literature reading materials in North Sumatra.
\end{abstract}

Keywords: development; reading material; children's literature; literacy

\section{Introduction}

Advances and technological sophistication are developing so fast that it creates modernization which causes the reading culture to shift. As a familiar expression that books are a window to the world, reading is opening a window to the world. However, in fact, in the current condition reading faces various problems such as boring and saturated reading, reading is less trendy with online games, reading is considered a waste of time, reading material is not suitable for the age of growth and psychological development of children, slow 
development of reading materials, selection of reading materials only modestly, interest in reading is low and reading habits are not yet entrenched. Regarding reading interest, the initial problems were obtained based on interviews conducted with grade 3 teachers at SDN 028228 Binjai (11 March 2020), which stated that not all students care about reading (literacy) activities. Followed by the results of the questionnaire obtained by the researcher, that students are not very interested in reading activities, and students also do not have interesting reading material. Of the 32 students, only 10 students who like to read and have interesting reading material.

Reading problems show the fact that the conditions of educational practice implemented in schools have not yet functioned as learning organizations that encourage all citizens to become lifelong learners. In fact, lifelong learning is an activity that must be carried out by all humans in order to adapt to the conditions of development and advancement of science. The government through the ministry of education and culture sparked new ideas to solve problems by developing the school literacy movement (GLS) as outlined in the regulation of the minister of education and culture number 23 of 2015 concerning the development of character, one of which is about reading non-textbooks for fifteen minutes. before study time begins.

The School Literacy Movement is an effort made to create a literate society which means people who have the ability to understand and apply what is read through daily behavior. A literate society is expected to behave in accordance with the knowledge previously read and understood so that their behavior has a basis. Habituation patterns regarding positive things at school need to be cultivated because this will also have a positive impact on habits outside of school. There are three stages determined through the guidelines issued by the Ministry of Education and Culture, namely 1) Introduction Stage, 2) Habitual Stage and 3) Development. The habituation stage is done by reading the enrichment book 15 minutes before the subject starts.

The development stage is carried out by responding to enrichment books to improve abilities and the learning stage is carried out by using enrichment books and reading strategies in all lessons. In line with literacy activities, Head of the Research and Development Agency (Kabalitbang) Toto Suprayitno (press release number: 397 / Sipres / A5.3 / XII / 2019) supports improving literacy, he asked schools to involve students more in reading, ensuring student summaries really conveyed in their own words is not just copying the contents of the reading, enriching the type of reading, and encouraging students to do reading activities as entertainment in their spare time. Based on the problems described, the researcher aims to develop a type of reading material that contains children's literature to support literacy activities.

Children's literature encompasses all kinds of creative and imaginative writing that are specifically for reading and entertaining children. Thus children's literature offers fun and understanding for children. Children's literature is closely related to the world of children and the language it uses is in accordance with children's intellectual and emotional development. Children's literature places children at the center of it. Some interpreted that children's literature was all books read and enjoyed by children. This statement is less agreed by Sutherland and Arthburnot (Hartati, 2017: 12), because children's literature is not only a book that is read and enjoyed by children, but is also written specifically for children and meets artistic standards and literary requirements. 
Children's literature has benefits for the child's side for intellectual development and emotional development (Samani, 2011:41)). Character is something that must be formed from the start because currently the character of the nation's children has begun to change and tends to decline. This is in line with the research conducted by Wuriyani (2017:5) which states that the benefits of children's literature are an alternative to environmental development to foster love for the natural wealth of the environment, such as folk tales found in the areas where children live. Therefore, in order for children to have good character in the future, guidance is needed, one of which is through developing children's literary reading materials for the school literacy movement. When viewed from the thematic syllabus of third grade elementary school students, theme 2 includes children's literature learning in the form of fairy tales with the sub-theme of the benefits of plants for human life. Seen on KD. 3.8 Describing messages in fairy tales that are presented orally, in writing, and visually with the aim of fun and KD. 4.8 Demonstrate messages in fairy tales as a form of self-expression using standard vocabulary and effective sentences. But in this study, the researcher chose the type of reading to be developed, namely comics. Comics are reading material in which there are stories and pictures equipped with characters that support a positive attitude. In addition, there are word balloons containing the contents of someone's words in the comic, so that students are easy to understand. This can increase students' interest in reading.

Comic reading material can also increase literacy and can even inspire children's imagination according to the child's development period. Comics have their own uniqueness compared to reading books for fairy tales, and others. Because comics have a row of pictures, panels, text balloons, and funny character and body movements. When reading, it seems as if you experience it (M. A. Lubis, 2017: 247). This research is limited to children's literature in North Sumatra. It is hoped that the researcher can support the literacy activities of students at SD Negeri 028228 Binjai as reading material for children's literature in comic form.

\section{Review of Literatures}

Reading material consists of two words, namely material and reading. The ability to read is very important for children. Children's abilities can more easily learn and master other fields of science (Gultom, 2021). When the ability to read becomes a culture in every child, the success rate at school and in community life will be even better (Nainggolan, 2020). The Big Indonesian Dictionary (Edition V) is anything that is used or needed for a specific purpose, while reading means books, etc. that can be read. Decree of the Minister of Home Affairs and Regional Autonomy Number 3 of 2001 concerning Village / Kelurahan Libraries provides that reading material is a printed medium provided to the public in the form of books, magazines, tabloids, newspapers, brochures, and other printed informative materials that can be read, studied and provide benefits to people's lives.

Children's literature is literature written by adults aimed at children or literature written by children for their own circles does not need to be questioned. Sarumpet (2010: 3) argues that children's literature is a literary work that is unique (to the world) of children, read by children, and - basically - guided by adults. While Ampera (2010:10) argues that children's literature is reading books or literary works that are deliberately written as children's reading, the contents are in accordance with children's interests and experiences, according to the level of emotional and intellectual development of children.

According to the KBBI (Big Indonesian Dictionary) comic is a story that is presented with pictures, which are funny so that they are identical and easy for all ages to digest. According to Gumelar (2011: 6) comic in Indonesian etymology comes from the word comic 
which more or less semantically means funny, a joke or the Greek word comicos revel which appeared around the 16th century. At first comics were intended to make pictures that tell stories. symbolically and interpretations of funny things. In its early history, comics actually started from comic strips, which were often found in several magazines or newspapers in the past. The first comic strip that appeared in the past on record was yellow kid. And along with its development, comics are no longer made as comic strips and their themes or genres are no longer inclined to funny things anymore, but are more widespread in other themes or genres ranging from action, horror to science fiction. Along with its development, comics, which were specifically jokes and tended to be for children, have begun to transform into teen and adult reading. His name in several countries has also changed from comics to graphic novels. A comic work can be called a graphic novel if it is published in more than one volume in series.

Kemdikbud, (2018: 11-12) states that literacy literally means 'literacy' or literacy. Furthermore, literacy has the development of meaning into 'understanding'. To be able to understand something, the ability to "read and write literacy" is the first and fundamental step for the development and mastery of literacy in other fields. Along with development, the term literacy continues to process and develop, but in essence literacy is interpreted as an understanding of the text and its context. Literary work is something that is produced by humans and is communicated to produce aesthetic values (Apriani, 2020).

\section{Research Methods}

This research uses research and development (Research \& Development), namely the development of comic reading materials to support the literacy activities of students at SDN 028228 Binjai. This research and development refers to the model development theory proposed by Borg and Gall. The research and development steps to be carried out are guided by Sugiyono (2016: 298-311), which originally consisted of 10 steps into 9 steps, namely as follows: (1) Potentials and Problems, (2) Data Collection, (3) Product Design, (4) Design Validation, (5) Design Revision, (6) Product Testing, (7) Product Revision, (8) Usage Trial, (9) Product Revision.

\section{Discussion}

The process of developing children's literature reading materials to support the literacy activities of SDN 028228 Binjai students is carried out in several stages. The development was carried out with the aim of producing literary reading materials for children in North Sumatra as well as seeing the effectiveness of the products used by 3 rd grade students of SDN 028228 Binjai as one of the school literacy movements. Therefore, this development process is carried out and begins with several stages, including: (1) conducting a preliminary study including observation and interviews. From the observation, it was found that students really need children's literature reading materials that support students' literacy activities in accordance with the characteristics of students. (2) designing a product to produce an initial product for reading material is carried out by a preliminary research which includes identification of needs. Based on the theory cited by Sunita \& Jha (2011: 263), needs analysis is a process for determining priority educational needs, gathering information and solving problems, identifying the characteristics and initial behavior of students. (3) developing children's literature reading materials to support students' literacy activities. This activity includes starting with designing the cover of reading material, information on the flow of comic reading, and some information related to folklore in North Sumatra. Children's literature reading materials to support students' literacy activities were developed to contain two folk tales in North 
Sumatra that were explained explicitly in reading material. (4) validating and revising, this activity includes product evaluation to find out the strengths, weaknesses and weaknesses of the quality of content and designs carried out by material and design experts. From the evaluation results will be used as material for product revisions.

The results of the validation are expected to get feedback to produce reading material that is suitable for use in accordance with the characteristics of students as users. This is in line with the opinion of Borg \& Gall (1983: 772) in the book Education Research and Education which states that development research is research oriented to develop and validate products used in education. After conducting a series of validations from material experts and design experts, the reading material developed gets feedback from the validator, then a revision is made based on suggestions and input from the experts to produce reading material that is suitable for use. From the validation data as a whole, the material expert validation covers six aspects with an average of $83.3 \%$ aspects on the "very good" criteria, and the design expert validation with an overall average of $88.3 \%$ on the "very good" criteria. The results of the response or responses made by the classroom teacher concluded that children's literature reading materials to support students' literacy activities were included in the "very good" criteria with a total average percentage of $93.3 \%$.

The results of the effectiveness of comic reading materials were obtained based on stage VI, namely the results of research on product effectiveness tests based on the reading material trials and the results of the pretest and posttest. The results of the individual trial test indicated that the reading material developed was included in the "good" criteria with an average total percentage of $79.6 \%$. The criteria for reading material feasibility are declared good because they are at the percentage interval of $61 \% \leq \mathrm{x}<80 \%$. The results of small group trials about students 'perceptions of children's literature reading materials to support students' literacy activities that have been developed show an average percentage of $88.2 \%$ with the criteria "very good". The criteria for reading material eligibility were stated to be very good because they were at the percentage interval of $81 \% \leq \mathrm{x}<100 \%$. The results of a limited field trial conducted by 32 students regarding students 'perceptions of children's literature reading materials to support students' literacy activities that have been developed show an average percentage of $90 \%$ with the criteria "very good". The criteria for reading material eligibility are very good because they are at the percentage interval of $81 \% \leq \mathrm{x}<100 \%$. Student learning outcomes are obtained by giving a trial test using comic reading materials that have been developed which aims to see the extent to which students' literacy activities have increased using reading materials that have been developed in this study. To achieve the learning objectives completely, one of the right ways to be taken is by making the right efforts to create a meaningful learning process. In the pretest results, it was found that 22 students did not pass the KKM score with an average score of $62.53 \%$, while the posttest results of 32 students who were above the KKM score were with an average score of $100 \%$.

Based on the theory cited by Wenny in Seloka: Journal of Indonesian Language and Literature Education (2015: 101), the effectiveness of comic reading materials can be seen from the results obtained by students during the learning process as evidenced by the increase in the average score of student learning outcomes. Student learning outcomes based on the pretest and posttest showed the difference between the pretest and posttest values obtained by $20.25 \%$ with an average pretest $68.40 \%$ and an average posttest $88.65 \%$. 


\section{Conclusion}

Based on the formulation, objectives, results, and discussion of research on the development of children's literature reading materials to support the literacy activities of students described previously, it can be concluded as follows:

1) The development of reading materials is based on the following procedures for research and development (Research and Development) by Borg and Gall, namely research and preliminary information collection, planning, initial product development, content validation and design, product revision, assessment and suggestions for class teachers and students, revision of individual trials, revision of group trials, revision of limited field trials, revisions until the product is valid and fit for use.

2) Testing the feasibility of children's literature reading materials to support students' literacy activities is carried out by material experts, design experts, Indonesian language teachers, and students. Children's literature reading materials to support students 'literacy activities are declared appropriate and can be used in students' literacy activities. In line with the results of the material expert validation covering six aspects with an average overall aspect of $83.3 \%$ on the "very good" criteria, and the design expert validation with an overall average of $88.3 \%$ on the "very good" criteria. The results of the assessment of teacher responses to children's literature reading materials to support students' literacy activities developed had a total average percentage of $93.3 \%$ with the criteria of "very good". The average percentage result of the entire limited field test is $90.1 \%$ with the criteria "very good". The results of the assessment based on the responses of teachers and students at SDN 028228 Binjai concluded that children's literature reading materials to support students' literacy activities that have been developed are declared to meet effective use because they are in accordance with the needs and obtain the overall criteria "very good". Therefore, the reading materials developed can foster enthusiasm for reading and improve students' understanding of faded folklore in North Sumatra.

3) The effectiveness of children's literature reading material developed as reading material for students' literacy activities is stated to have made a useful and effective contribution in improving the quality of the literacy activities of SDN 028228 Binjai students. This is because there is a significant difference to the results of students 'literacy activities after using comic book reading materials (posttest) with an average score of $88.65 \%$, while students' literacy activities before using comic reading materials (pretest) with an average score of $68.40 \%$. The difference in these results shows that the average value of the results of students' literacy activities increases with an increase of $20.25 \%$. The scores obtained by students also showed that the results of students 'literacy activities through the pretest had the lowest score of 56 and the highest score of 80 , while the results of students' literacy activities through posttest (comic reading material) had the lowest score of 73 and the highest score of 98 .

\section{References}

Ampera, Taufik. 2010. Pengajaran Sastra Anak Teknik Mengajar Sastra Anak.: Berbasis Aktivitas. Bandung: Widya Padjadjaran.

Apriani, P., Saragih, E., and Rosliani. (2020). Moral and Religious Values in the Novel "Negeri Lima Menara" by A. Fuadi and its Relationship as Reading Materials in SchoolsYear 2020/2021. Britain International of Linguistics, Arts and Education(BIoLAE) Journal Vol. 2 (3): 747-764.

Bolg, W.R. \& Gall, M.D. Gall. 1983. Education Research: An. Introduction, Fifth Edition. New York: Longman. 
Gultom, O., Yus, A., and Sriadhi. (2021). Development of Interactive Learning Multimedia Reading Early Children's Beginning. Budapest International Research and Critics in Linguistics and Education (BirLE) Journal Vol 4 (1): 24-34.

Gumelar, M.S. 2011. Comic Making. Jakarta: PT. Indeks.

Hartati, T. 2017. Apresiasi Sastra Anak. Bandung: Pascasarjana UPI.

Hidayah, Nurul. 2017. Pengembangan Media Pembelajaran Berbasis Komik Pada Mata Pelajaran Ilmu Pengetahuan Sosial Kelas Iv Mi Nurul Hidayah Roworejo Negerikaton Pesawaran. Lampung: Jurnal Pendidikan dan Pembelajaran Dasar Volume 4 Nomor 1 Juni 2017.

Kemdikbud. 2018. Gerakan Literasi Sekolah. Jakarta: Pusat Penelitian Kebijakan Pendidikan dan Kebudayaan, Badan Penelitian dan Pengembangan, Kementerian Pendidikan dan Kebudayaan.

Lubis, A., Sari, M., Yunita, I., Keguruan, I., Padangsidempuan, I., Tarbiyah, F., ... Balai, S. A. T. 2017. Kualitas Bahan Ajar Komik Dalam Tingkat Pemahaman Belajar Peserta Didik, 45-50.

Muktar, et. al. (2019). Reading is one of the most important ways to obtain important information and knowledge. Britain International of Linguistics, Arts and Education (BIoLAE) Journal Vol.1 (2): 210-223.

Nainggolan, C., and Rosliani. (2020). The Development Of Literacy Reading Books of North Sumatera Fairy Tale For V Grade Students at Elementary School. Britain International of Linguistics, Arts and Education(BIoLAE) Journal Vol. 2 (3): 724-737.

Nurgiyantoro, Burhan. 2016. Sastra Anak Pengantar Pemahaman Dunia Anak. Yogyakarta: UGM Press.

Pengembangan Komik Akidah Akhlak Untuk Meningkatkan Minat Baca dan Prestasi Belajar Siswa Sekolah Dasar. Halaqa: Islamic Education Journal, 1(1). Retrieved from http://ojs.umsida.ac.id/index.php/halaqa.

PISA.2015. https://nces.ed.gov/surveys/pisa/pisa2015/pisa2015highlights_4.asp.

Sarumpet, Riris Toha. 2010. Pedoman Penelitian Sastra Anak. Jakarta: Yayasan Obor Indonesia.

Sugiyono. 2016. Metode Penelitian Pendidikan Pendekatan Kuantitatif, Kualitatif, dan R\&D. Bandung: Alfabeta.

Wijanti, Wenny. 2015. Pengembangan Bahan Ajar Interaktif Kompetensi Memproduksi Teks Prosesdur Kompleks yang Bermuatan Kesantunan bagi Peserta Didik Kelas X SMS/MA. Semarang: Seloka: Jurnal Pendidikan Bahasa dan Sastra Indonesia.

Winarni, Retno. 2014. Kajian Sastra Anak. Yogyakarta: Graha Ilmu.

Wuriyani, Elly Prihasti. (2017). Sastra sebagai Alternatif Kebangkitan Berlingkungan. Medan: Universitas Negeri Medan. 